\title{
Controlling the Risk of Construction Delay in the Middle
}

\section{East: State-of-the-Art Review}

\author{
Omayma Hashim Motaleb ${ }^{1}$ and Mohammed Kishk ${ }^{2}$ \\ 1. Faculty of Engineering, UAEU (United Arab Emirates University), Al Ain 20571, United Arab Emirates \\ 2. The Scott Sutherland School of Architecture and Built Environment, Robert Gordon University, Aberdeen AB10 7QB, UK
}

\begin{abstract}
The financial crisis in late 2008 arrested economic development in the construction sector in the Middle East, with the result that investors' confidence in the sector is severely depressed. Delays constitute one of the highest impediments to project success. In this respect, the traditional management is no longer sufficient for construction project success. The objective of this study is to conduct a literature review to identify additional effective measures for controlling the potential delays risks in construction projects in order to maximize the opportunities for success in those projects. Thirty-six scholarly articles published between 2000 and 2011 are reviewed to identify related MDRC (measures for delays risks control). This survey reveals that $60 \%$ of the studies are related to decision-making, performance, risk management variations and poor management knowledge of stakeholders and that $20 \%$ of these studies are undertaken in the Middle East. A further $25 \%$ of the studies are related to the lack of financial risk by stakeholders, and of these $14 \%$ are in the Middle East. A knowledge gap is identified in terms of project performance, stakeholder management and risk management, which are seen as significant measures of success in controlling project delay.
\end{abstract}

Key words: Measures of delays risks control, risk management, project management, stakeholders, Middle East.

\section{Introduction}

Construction delay is ubiquitous in the Middle East construction business and considered as one of the highest risks that can hamper project success. This phenomenon is largely due to the overlapping roles and interests of the project stakeholders in a multicultural society. Stakeholders have long been involved in construction projects, as either individuals or organizations. Moreover, their interests might be affected positively or negatively according to the success or failure of the project completion [1]. Mitchell et al. [2] argued that a project manager must understand the characteristics of the stakeholders' power and authority that largely affect the project environment and outcomes. Hence, it is important to identify stakeholders and their management input

Corresponding author: Omayma Hashim Motaleb, Ph.D., assistant professor, research fields: risk management in construction projects, knowledge management performance for project stakeholders, project stakeholders management and building technology.E-mail: omaimahashim@hotmail.com. throughout the duration of a project, since their nature and numbers could vary with the project life-cycle [3]. Accordingly, stakeholders should update their respective commitments and satisfaction, with a view to improving the chances of project success.

Risk management is the most crucial practice in the management of any project if completion is to be achieved. Royer [4] expressed the importance of risk management experience, saying: "experience in the risk management must be of critical concern to the project managers and the like in the project network since ill-managed risks are one of the primary causes of project failure". Unfortunately, many project stakeholders and contributors have not yet realized the need for risk assessment knowledge, which is a key element in the risk-management process, and some actually believe that risk identification is only achieved by trial and error experience. Artto et al. [5] defined risk from the project management perspective as "an uncertain event or condition (favorable or 
unfavorable) that results from the network form of work, having an impact that contradicts expectations. An event is at least partially related to other actors in a network". Referring to this definition, four risk-source categories have been identified based on the project sub-contractors' interrelations with: (1) other sub-contractors; (2) clients; (3) external competitors; and (4) non-business actors such as the municipality and other area authorities [5]. At the same time, it is accepted that lack of professional managerial knowledge and skills might cause unavoidable risk management failure [6]. The risk of construction project cancellation and delay in the Middle East, particularly in Dubai, has evoked many worries among investors about remaining in the construction business [7].

Project delays have a major negative impact on stakeholders whose economic activities have been depressed, and in the Middle East, this situation is prevalent, as stakeholders are notably dissatisfied. Nonetheless, they are being criticized as they are not dynamically involved in the process of delay control, which requires a concerted approach in order to guarantee project success. The risk of project delays has been investigated in many Middle Eastern countries such as Jordan [8, 9], Kuwait [10, 11], Saudi Arabia [12], the UAE (United Arab Emirates) [13, 14], Oman [15] and Iran [16]. However, these studies have focused entirely on the delay causes and effects rather than on the control aspects. At the same time, the recent global financial crisis has slowed down the construction boom, leading to the postponement and cancellation of construction projects that are already underway. The financial difficulties resulting from the crisis have created the great dilemma whereby stakeholders have experienced shortages in cash liquidity which in turn has resulted in delayed payments to real estate developers, and subsequently to delays in project schedules and completion [17].

The key objective of delay control management is to minimize the risk whilst maximizing the opportunities for successful project completion. If this objective is to be achieved by the stakeholders' management, those responsible for initiating and formulating projects must be capable in this respect. In this study, a number of significant MDRC (measures for delay risks control) were selected from 36 scholarly studies published between 2000 and 2011, which included delays to construction projects resulting from the effects of the global financial crisis. The outcome of this study is expected to encourage further comprehensive research. The paper is organized as follows: Section 2 discusses the stakeholders' management and satisfaction when criteria beyond the traditional ones are used; Section 3 outlines the research methodology adopted, which seeks to improve the stakeholders' management, and identify a number of MDRC as a means of bridging the knowledge gap caused by the traditional criteria of time, cost and quality; Section 4 discusses the findings; and Section 5 provides constructive conclusions and recommendations for further related studies. A list of the cited references appears in References Section.

\section{Beyond the Traditional Criteria and Stakeholder Satisfaction}

Although the traditional criteria for project success are widely accepted, in the last two decades, construction project management has shown a slow departure from the traditional criteria (time, cost and quality) measures towards more effective measures, since criticisms have been made of the traditional criteria in their ability to enable success. Specifically, it is accepted that whilst the components of time, cost, and quality are indeed important, it is also essential to meet the precise specifications of a project [18]. Additionally, Alarcon et al. [19] criticized the criteria as being unable to produce long-term improvement and for being considered too late in the project life cycle to correct problems, thereby not being capable of guaranteeing quality. Hence, it is recognized that 
project success can no longer be expected purely by adhering to the traditional criteria only [20], since they are too basic to function as internal measures of project management efficiency [21]. It is noted that, to improve efficiency, projects should aim to manage risks better, and that the degree to which risks are managed should be a measure in this respect.

The fact that stakeholders have conflicting interests brings different views regarding what constitutes project success and satisfaction [22], and these variations cause stakeholders to try to exert influence over projects in different degrees. Clearly, stakeholders have significant knowledge concerning particular aspects of a project and that knowledge could be valuable in formulating the risk response strategy [23]. This suggests the potential for an innovative knowledge framework that would allow for the continual building of a stakeholder body of knowledge and for better overall management of risks [24].

The most important issue to be considered in respect of project success criteria is the extent of the influential variables caused by stakeholders in relation to the performance, decision-making and variations to the project. Although performance is generally considered to be the outcome of the traditional components, cost benefits saving [25], early completion [26], improve quality [27], there is also a fact that conflicts occur due to stakeholders' dissatisfaction with the quality of overall work.

According to the nature changing of buildings functions and demands, performance should be considered as particular to each project and therefore might be evaluated differently according to the precise circumstances of the project [28]. Satisfaction in respect of project performance is essential in a world of hyper-competition, and where construction projects suffer from delay and budget overrun, it is an important criterion to meet. Powerful construction organizations are seen to compete in the marketplace by creating value for their stakeholders [29]. But studies are required to explore in more depth how different stakeholders perform in terms of management and their perception of risk assessment. Landin [30] considered that, to achieve long-term construction project performance, stakeholder satisfaction is crucial and other researchers, Bakens et al. [31] and Young [32] noted the importance of effective communications management.

The empowerment of stakeholders in decision-making has been encouraged in project management, but has always been limited, as it has been thought more important for stakeholders to set goals and keep inventories, leaving planning and other decisions to expert stakeholders or teams that have a greater impact on decision-making effectiveness. The aim has been to complete projects on time, within budget and within specifications [33], and significant historical information and knowledge has been used to improve decision-making and the outcome of project control [34].

Variations/change orders requested by clients, contractors or other stakeholders were shown to have increased project delays in Jordan [35], and in the UAE context, excessive clients change orders [36]. Likewise, in Oman, change orders invoked by the clients and consultants [15] are cited as being prevalent, with the result that schedules are delayed, stakeholders come into conflict and costs are exceeded. Arain [37] argues that if knowledge is effectively shared during the earlier project life cycle stages, variations management can be better discharged.

Additionally, financial measures are important since the potential loss of revenue can arise in respect of any of the stakeholders' mismanagement of their finances or fundamental inability to pay [38, 39]. Delays in payment by the client, poor cash flow on the part of the contractor [40-42], and financial delays caused by bankers, quantity surveyors, architects, consultants, and other construction parties may affect directly or indirectly the process of payment and the continuation of work according to schedule. Invalid 
claims by contractors, certification delays by consultants poor work valuation and insufficient documentation, the involvement of too many stakeholders in the certification process, and the heavy workload placed on consultants to work on evaluations are all cited as contributors to difficulties in the financial area. Moreover, the outcomes of the financial crisis (2008-2010) on the Middle East are enormous. Clearly, such constraints on the cash flow associated with the full range of stakeholders have led to delays in payments.

Market forces are of importance in this respect, since inflations and the endemic instability in the financial market have generated cash flow issues [40] and the inability of governments to create funding programmes [43]. Khamis and Senhadji [17] observe this situation as very serious in the Middle East where the global financial crisis has brought difficulties in approving and obtaining loans, thereby causing a crisis within the GCC (Gulf Cooperation Council) real estate markets. In this context, the stakeholders (developers) and the associated financial bodies are among the largest openly scheduled companies in Arab markets, and both were adversely affected by the recession. At the same time, the increase in real estate prices in the Middle East ended in 2008 and the average inflation rate declined from $10.8 \%$ in 2008 to $3.7 \%$ in 2009 [44]. In turn, the banks stopped giving mortgages. And as a result, many banks came under financial distress.

\section{Research Methodology}

A literature review was undertaken to identify the gaps in delays control and project success. Thirty-six research studies published in scholarly and refereed journals associated with construction projects were reviewed, together with some non-conventional documents such as dissertations, technical reports, working papers and authenticated websites, as listed in Table 1. The data were analyzed using an Excel spreadsheet.

\section{Findings and Discussions}

The results of the study are summarized in Table 1. It can be seen that the MDRC was 3\% in 2000, $8 \%$ in 2002, and decreased in 2003 and 2004 to 3\%. In 2005-2006, measures improved were $14 \%$ and $16 \%$, respectively, and decreased again to $3 \%$ in 2007 , and 6\% in 2008 and clearly improved in 2009 and 2010, to $19 \%$ and 31\%, respectively, as illustrated in Fig. 1.

The MDRC have been grouped as follows: Group 1 comprises decision-making, performance, variations and risk management, Group 2 comprises the financial risks, and Group 3 comprises the traditional measures of time, cost and quality.

Group 1 accounts for $60 \%$ of studies (2000-2011) which are related to stakeholders' management and knowledge in variations and decision-making. These pay limited attention to risk management and performance issues. Between 2008 and 2011, these studies represented $30 \%$ of those reported.

Group 2 accounts for $25 \%$ of studies and are related to financial risk. Between 2008-2011, they represented $20 \%$ of studies and reflected interest generated as a result of the financial crisis.

Group 3 accounts for the remaining 15\% of studies relating to the traditional criteria of time, cost and quality.

It is shown in Fig. 2 that about $60 \%$ of studies have focused on the level of stakeholder management (Group1), worldwide and that of these 25\% have been conducted in the Middle East. Twenty-five percent of the selected research has been identified by Group2. Financial risk in global including the Middle East represented $14 \%$, and $15 \%$ for the traditional measures in global.

As a result, the ranking of MDRC issues associated with construction projects shows stakeholders' lack of management ability and knowledge in the specific area of risk management, performance, variations and decision-making, running from top to bottom, with the financial risk following, as illustrated in Fig. 2. 
Table 1 Measures for delays risks control.

\begin{tabular}{|c|c|c|c|c|c|}
\hline No. & \begin{tabular}{|l} 
Studies/country \\
(region)
\end{tabular} & MDRC & Research method & $\begin{array}{l}\text { Causes and effects of } \\
\text { delay }\end{array}$ & $\begin{array}{l}\text { Impact on } \\
\text { stakeholders }\end{array}$ \\
\hline 1 & $\begin{array}{l}\mathrm{Ng} \text { et al./ } \\
\text { Hong Kong } \\
\text { (Asia) }[45]\end{array}$ & $\begin{array}{l}\text { A conceptual case-based decision } \\
\text { model for construction delays } \\
\text { mitigation (Group 1) }\end{array}$ & Quantitative & $\begin{array}{l}\text { Slow-decision by } \\
\text { contractor }\end{array}$ & \begin{tabular}{|l|} 
Increase \\
knowledge_good for \\
inexperienced planner \\
\end{tabular} \\
\hline 2 & $\begin{array}{l}\text { Odeh and } \\
\text { Battaineh/Jordan [9] } \\
\text { (Middle East) }\end{array}$ & $\begin{array}{l}\text { Contract performance } \\
\text { development (Groups } 1 \text { and 2) }\end{array}$ & $\begin{array}{l}\text { Quantitative } \\
\text { (questionnaire ) }\end{array}$ & $\begin{array}{l}\text { Owner interference, } \\
\text { inadequate contractor, } \\
\text { financial, labour } \\
\text { productivity slow } \\
\text { decision-making }\end{array}$ & $\begin{array}{l}\text { Minimize owner } \\
\text { interference, labour } \\
\text { and finance }\end{array}$ \\
\hline 3 & \begin{tabular}{|l|} 
Aibinu and \\
Jagboro/Nigeria \\
(Africa) [34] \\
\end{tabular} & $\begin{array}{l}\text { Acceleration of site activities and } \\
\text { contingency allowance (Group3) }\end{array}$ & $\begin{array}{l}\text { Quantitative } \\
\text { (questionnaire) }\end{array}$ & Client-related delay & $\begin{array}{l}\text { Eliminate time } \\
\text { overrun }\end{array}$ \\
\hline 4 & $\begin{array}{l}\text { Shenhar et al./(N/A) } \\
{[46]}\end{array}$ & $\begin{array}{l}\text { Risk identification, probabilistic } \\
\text { risk and trade off (Group 1) }\end{array}$ & $\begin{array}{l}\text { Quantitative } \\
\text { (100 projects) }\end{array}$ & Time overrun & $\begin{array}{l}\text { Improve risk } \\
\text { management }\end{array}$ \\
\hline 5 & Fernie et al./(N/A) [47] & Knowledge sharing (Group1) & $\begin{array}{l}\text { Quantative } \\
\text { (observations ) }\end{array}$ & $\begin{array}{l}\text { Knowledge } \\
\text { problematic }\end{array}$ & Lesson learned \\
\hline 6 & $\begin{array}{l}\text { Nguyen/Vietnam } \\
\text { (Asia) [48] }\end{array}$ & $\begin{array}{l}\text { COMs (comfort, competence and } \\
\text { commitments) (Group 1) }\end{array}$ & $\begin{array}{l}\text { Quantitative } \\
\text { (questionnaire) }\end{array}$ & $\begin{array}{l}\text { Complexity of } \\
\text { projects (many } \\
\text { factors) }\end{array}$ & $\begin{array}{l}\text { Improve knowledge in } \\
\text { project handling }\end{array}$ \\
\hline 7 & Lee et al./(N/A) [49] & $\begin{array}{l}\text { DPM (dynamic planning and } \\
\text { control management) for project } \\
\text { change management (Group 1) }\end{array}$ & $\begin{array}{l}\text { Exploratory } \\
\text { (case study) }\end{array}$ & $\begin{array}{l}\text { Concurrent design } \\
\text { changes and their } \\
\text { subsequent impacts on } \\
\text { project performance } \\
\end{array}$ & $\begin{array}{l}\text { Cost and schedule } \\
\text { control }\end{array}$ \\
\hline 8 & Lee et al./USA [50] & $\begin{array}{l}\text { Converted lost productivity into } \\
\text { delay duration (Group3 ) }\end{array}$ & $\begin{array}{l}\text { Quantitative } \\
\text { (case study) }\end{array}$ & Lost productivity & $\begin{array}{l}\text { Settlement of schedule } \\
\text { delay }\end{array}$ \\
\hline 9 & $\begin{array}{l}\text { Arain/Singapore } \\
\text { (Asia) [37] }\end{array}$ & $\begin{array}{l}\text { KBDSS (knowledge-based } \\
\text { decision support system)(Group } \\
1 \text { ) }\end{array}$ & $\begin{array}{l}\text { Quantitative } \\
\text { (questionnaire, } \\
\text { depth interview) }\end{array}$ & $\begin{array}{l}\text { Owner and contractor- } \\
\text { related project } \\
\text { variations }\end{array}$ & $\begin{array}{l}\text { Control variation } \\
\text { orders and improve } \\
\text { decision-making }\end{array}$ \\
\hline 10 & Oliveros/(N/A) [51] & $\begin{array}{l}\text { Fuzzy logic model } \\
\text { (Group 3) }\end{array}$ & $\begin{array}{l}\text { Quantitative } \\
\text { (empirical) }\end{array}$ & Time overrun & \begin{tabular}{|l|}
$\begin{array}{l}\text { Updating project } \\
\text { schedule }\end{array}$ \\
\end{tabular} \\
\hline 11 & $\begin{array}{l}\text { Koushki/Kuwiat } \\
\text { (Middle East) [11] }\end{array}$ & $\begin{array}{l}\text { Adequate funds, good allocation } \\
\text { of time and money, competent } \\
\text { consultants and contractors } \\
\text { (Group } 1 \text { and } 2 \text { ) }\end{array}$ & $\begin{array}{l}\text { Quantitative } \\
\text { (personal } \\
\text { interviews) }\end{array}$ & $\begin{array}{l}\text { Time delay and cost } \\
\text { overrun }\end{array}$ & $\begin{array}{l}\text { Minimize time and } \\
\text { cost overrun }\end{array}$ \\
\hline 12 & $\begin{array}{l}\text { Wang and Haung/China } \\
{[52]}\end{array}$ & Relation criterion (Group 1) & $\begin{array}{l}\text { Quantitative } \\
\text { (questionnaire) }\end{array}$ & $\begin{array}{l}\text { Poor stakeholders } \\
\text { performance }\end{array}$ & $\begin{array}{l}\text { Maximize owner and } \\
\text { organization } \\
\text { performance }\end{array}$ \\
\hline 13 & \begin{tabular}{|l} 
Shahalizadeh and \\
Farhadyar/Iran (Middle \\
East) [53]
\end{tabular} & $\begin{array}{l}\text { Knowledge management } \\
\text { (Group1) }\end{array}$ & $\begin{array}{l}\text { Quantitative } \\
\text { (questionnaire ) }\end{array}$ & Waste time and cost & Lesson learnt \\
\hline 14 & $\begin{array}{l}\text { Abdul-Rahman et al. } \\
\text { /Malaysia } \\
\text { (Asia) [43] }\end{array}$ & $\begin{array}{l}\text { Effective management method } \\
\text { (Group1) }\end{array}$ & Quantitative & $\begin{array}{l}\text { Uncertainty and more } \\
\text { variables }\end{array}$ & $\begin{array}{l}\text { Reduce } \\
\text { diversions/variations }\end{array}$ \\
\hline 15 & $\begin{array}{l}\text { Zaneldin/UAE } \\
\text { (Middle East) [54] }\end{array}$ & $\begin{array}{l}\text { The negotiation used to resolve } \\
\text { construction claims (Group 1) }\end{array}$ & $\begin{array}{l}\text { Quantitative (124 } \\
\text { claims) }\end{array}$ & $\begin{array}{l}\text { Excessive client } \\
\text { orders }\end{array}$ & \begin{tabular}{|l|} 
Avoiding disputes, \\
good knowledge from \\
past projects; \\
cooperation by risk \\
philosophy between the \\
client and the contractor
\end{tabular} \\
\hline 16 & $\begin{array}{l}\text { Arditi and } \\
\text { Pattanakitchamroon/ } \\
\text { N/A [55] }\end{array}$ & $\begin{array}{l}\text { Selection of proper delay analysis } \\
\text { method } \\
\text { (Group 3) }\end{array}$ & $\begin{array}{l}\text { Exploratory ( } 20 \\
\text { researches from } \\
\text { literature) }\end{array}$ & Time overrun & $\begin{array}{l}\text { Availability of } \\
\text { scheduling data }\end{array}$ \\
\hline 17 & Oladapo/N/A [56] & $\begin{array}{l}\text { Variations management } \\
\text { (Group 1) }\end{array}$ & \begin{tabular}{|l} 
Quantitative \\
(questionnaire and \\
30 buildings) \\
\end{tabular} & Time and cost overrun & Managing variations \\
\hline 18 & Zeng et al./(N/A) [57] & $\begin{array}{l}\text { Fuzzy reasoning techniques of } \\
\text { risk assessment (Group 1) }\end{array}$ & Exploratory & Uncertainty & Risk assessment \\
\hline
\end{tabular}


(Table 1 continued)

\begin{tabular}{|c|c|c|c|c|c|}
\hline No. & $\begin{array}{l}\text { Studies } \\
\text { /country } \\
\text { (region) }\end{array}$ & MDRC & Research method & $\begin{array}{l}\text { Causes and effects of } \\
\text { delay }\end{array}$ & $\begin{array}{l}\text { Impact on } \\
\text { stakeholders }\end{array}$ \\
\hline 19 & $\begin{array}{l}\text { Abdul-Rahman et } \\
\text { al./Malaysia (Asia) } \\
{[58]}\end{array}$ & $\begin{array}{l}\text { Conceptual delay mitigation } \\
\text { model using a project learning } \\
\text { approach in practice (Group 1) }\end{array}$ & \begin{tabular}{|l} 
Exploratory \\
(literature, developed \\
model, case studies, \\
questionnaire) \\
\end{tabular} & Poor project knowledge & $\begin{array}{l}\text { Improve knowledge, } \\
\text { positive schedule and } \\
\text { performance }\end{array}$ \\
\hline 20 & $\begin{array}{l}\text { Luu et al./(N/A) } \\
{[39]}\end{array}$ & $\begin{array}{l}\text { Bayesian belief networks } \\
\text { (Group 2) }\end{array}$ & $\begin{array}{l}\text { Quantitative } \\
\text { (questionnaire, expert } \\
\text { interviews, case } \\
\text { studies) } \\
\end{array}$ & \begin{tabular}{|l|} 
Financial difficulties by \\
owner and contractor \\
and shortage of \\
materials
\end{tabular} & $\begin{array}{l}\text { Financial and time } \\
\text { development for } \\
\text { stakeholders }\end{array}$ \\
\hline 21 & $\begin{array}{l}\text { Abdul-Rahman et } \\
\text { al./Malaysia } \\
\text { (Asia) [59] } \\
\end{array}$ & $\begin{array}{l}\text { Well managed cash flow by } \\
\text { banks (Group2) }\end{array}$ & Quantitative & $\begin{array}{l}\text { Financial related factor } \\
\text { by client }\end{array}$ & $\begin{array}{l}\text { Prompt payment } \\
\text { practice }\end{array}$ \\
\hline 22 & $\begin{array}{l}\text { Tumi et al./Libya } \\
\text { (Africa) [60] }\end{array}$ & $\begin{array}{l}\text { Risk management } \\
\text { (Group1) }\end{array}$ & $\begin{array}{l}\text { Quantitative } \\
\text { (questionnaire) }\end{array}$ & $\begin{array}{l}\text { Ineffective } \\
\text { co-ordination and } \\
\text { communication } \\
\end{array}$ & $\begin{array}{l}\text { Performance } \\
\text { knowledge }\end{array}$ \\
\hline 23 & Mulcahy/(N/A) [23] & Corrective action (Group 3) & $\begin{array}{l}\text { tory from field } \\
\text { ice }\end{array}$ & $\begin{array}{l}\text { Activity longer } \\
\text { estimation }\end{array}$ & $\begin{array}{l}\text { close to } \\
\text { e }\end{array}$ \\
\hline 24 & $\begin{array}{l}\text { Motaleb/UAE } \\
\text { (Middle East) [14] }\end{array}$ & $\begin{array}{l}\text { CMCS (collaboration, } \\
\text { management and control } \\
\text { solution) (Group 1) }\end{array}$ & $\begin{array}{l}\text { Quantitative } \\
\text { (questionnaire) }\end{array}$ & $\begin{array}{l}\text { of risk } \\
\text { gement }\end{array}$ & $\begin{array}{l}\text { Improve risk } \\
\text { knowledge }\end{array}$ \\
\hline 25 & $\begin{array}{l}\text { Said/Saudi Arabia } \\
\text { (Middle East) [61] }\end{array}$ & $\begin{array}{l}\text { Corrective action optimization } \\
\text { (Group1) }\end{array}$ & $\begin{array}{l}\text { Exploratory } \\
\text { (literature, case } \\
\text { studies) }\end{array}$ & $\begin{array}{l}\text { Rework that caused time } \\
\text { and cost overrun }\end{array}$ & Control performance \\
\hline 26 & \begin{tabular}{|l|} 
Motaleb and \\
Kishk/UAE \\
(Middle East) [62] \\
\end{tabular} & $\begin{array}{l}\text { Client and project team training } \\
\text { (Group 1) }\end{array}$ & $\begin{array}{l}\text { Quantitative } \\
\text { (questionnaire) }\end{array}$ & Excessive client orders & $\begin{array}{l}\text { Improve client } \\
\text { decision-making and } \\
\text { reduce variations }\end{array}$ \\
\hline 27 & $\begin{array}{l}\text { Thanh and } \\
\text { Dapice/(N/A) [63] }\end{array}$ & $\begin{array}{l}\text { Controlling and preventing } \\
\text { delay of sub-project (Group 3) }\end{array}$ & $\begin{array}{l}\text { Exploratory (case } \\
\text { studies) }\end{array}$ & \begin{tabular}{|l|}
$\begin{array}{l}\text { Poor planning and } \\
\text { controlling, poor finance } \\
\text { contractor competence }\end{array}$ \\
\end{tabular} & $\begin{array}{l}\text { Time delay overcome } \\
\text { and efficiency during } \\
\text { construction }\end{array}$ \\
\hline 28 & $\begin{array}{l}\text { Preston/Gulf } \\
\text { (Middle East) [64] }\end{array}$ & $\begin{array}{l}\text { Liquidated damages for delay } \\
\text { (Groups } 1 \text { and } 2 \text { ) }\end{array}$ & $\begin{array}{l}\text { Exploratory } \\
\text { (literature) }\end{array}$ & $\begin{array}{l}\text { Financial (2010 gulf } \\
\text { recession) }\end{array}$ & $\begin{array}{l}\text { Adjust the contractor } \\
\text { finance risk and } \\
\text { performance } \\
\text { obligations } \\
\end{array}$ \\
\hline 29 & $\begin{array}{l}\text { Omran et } \\
\text { al./Malaysia [65] }\end{array}$ & $\begin{array}{l}\text { Working drawing stage solve } \\
\text { problem (Group 1) }\end{array}$ & $\begin{array}{l}\text { Quantitative } \\
\text { (questionnaire) }\end{array}$ & $\begin{array}{l}\text { Contractor related factor } \\
\text { and owner's slow } \\
\text { decision making }\end{array}$ & $\begin{array}{l}\text { Preconstruction } \\
\text { knowledge }\end{array}$ \\
\hline 30 & $\begin{array}{l}\text { Olawale and } \\
\text { Sun/UK [66] }\end{array}$ & $\begin{array}{l}\text { Preventive, predictive, } \\
\text { corrective and organizational } \\
\text { measures } \\
\text { (Groups } 1 \text { and } 3 \text { ) }\end{array}$ & $\begin{array}{l}\text { Exploratory } \\
\text { (face-to-face } \\
\text { interviews) }\end{array}$ & \begin{tabular}{|l|} 
Design changes \\
inaccurate time \\
duration, subcontractor \\
inadequate performance \\
\end{tabular} & $\begin{array}{l}\text { Improve the } \\
\text { effectiveness of } \\
\text { project control (cost } \\
\text { and time control) } \\
\end{array}$ \\
\hline 31 & Manase/UK [67] & $\begin{array}{l}\text { The PFI (private finance } \\
\text { initiative) procurement (Groups } \\
1 \text { and 2) }\end{array}$ & $\begin{array}{l}\text { Expolarotary } \\
\text { (literature review) }\end{array}$ & $\begin{array}{l}\text { Financial-related crisis } \\
2009\end{array}$ & $\begin{array}{l}\text { Client positioning in } \\
\text { term of risk allocation }\end{array}$ \\
\hline 32 & \begin{tabular}{|l} 
Hasna and \\
Raza/GCC \\
(Middle East) [22]
\end{tabular} & $\begin{array}{l}\text { PPM (project portfolio } \\
\text { management) (Group 2) }\end{array}$ & Exploratory & $\begin{array}{l}\text { Financial problems } \\
\text { uncontrolled budget }\end{array}$ & $\begin{array}{l}\text { Good knowledge of } \\
\text { financial resources }\end{array}$ \\
\hline 33 & $\begin{array}{l}\text { Arditi et al./(N/A) } \\
{[68]}\end{array}$ & $\begin{array}{l}\text { Lesson learned system } \\
\text { (Group 1) }\end{array}$ & Exploratory data base & Design related problems & $\begin{array}{l}\text { Avoiding the same } \\
\text { mistakes in the past } \\
\text { projects_improve } \\
\text { knowledge }\end{array}$ \\
\hline 34 & $\begin{array}{l}\text { Brendel et al./UAE } \\
\text { (Middle East) [69] }\end{array}$ & $\begin{array}{l}\text { Set up qualified civil rights for } \\
\text { contractors to assured payment } \\
\text { for work (Groups } 1 \text { and 2) }\end{array}$ & $\begin{array}{l}\text { Exploratory } \\
\text { (literature) }\end{array}$ & $\begin{array}{l}\text { Financial } \\
\text { contractor-related }\end{array}$ & $\begin{array}{l}\text { Knowledge of civil } \\
\text { code and code } \\
\text { provisions }\end{array}$ \\
\hline 35 & $\begin{array}{l}\text { Al Tmeemy et } \\
\text { al./(N/A) [70] }\end{array}$ & $\begin{array}{l}\text { Project management, product } \\
\text { and market success measures } \\
\text { (Group 1) }\end{array}$ & $\begin{array}{l}\text { Quantitative (postal } \\
\text { and e-mail survey) }\end{array}$ & $\begin{array}{l}\text { Failure in (cost, time } \\
\text { and quality) }\end{array}$ & $\begin{array}{l}\text { Long-term project } \\
\text { success }\end{array}$ \\
\hline 36 & $\begin{array}{l}\text { Abdul-Rahman et } \\
\text { al./(N/A) [71] }\end{array}$ & $\begin{array}{l}\text { Cash flow management (Group } \\
\text { 2) }\end{array}$ & $\begin{array}{l}\text { Quantitative } \\
\text { (interviews) }\end{array}$ & Financial client-related & $\begin{array}{l}\text { Prompt payments by } \\
\text { client }\end{array}$ \\
\hline
\end{tabular}




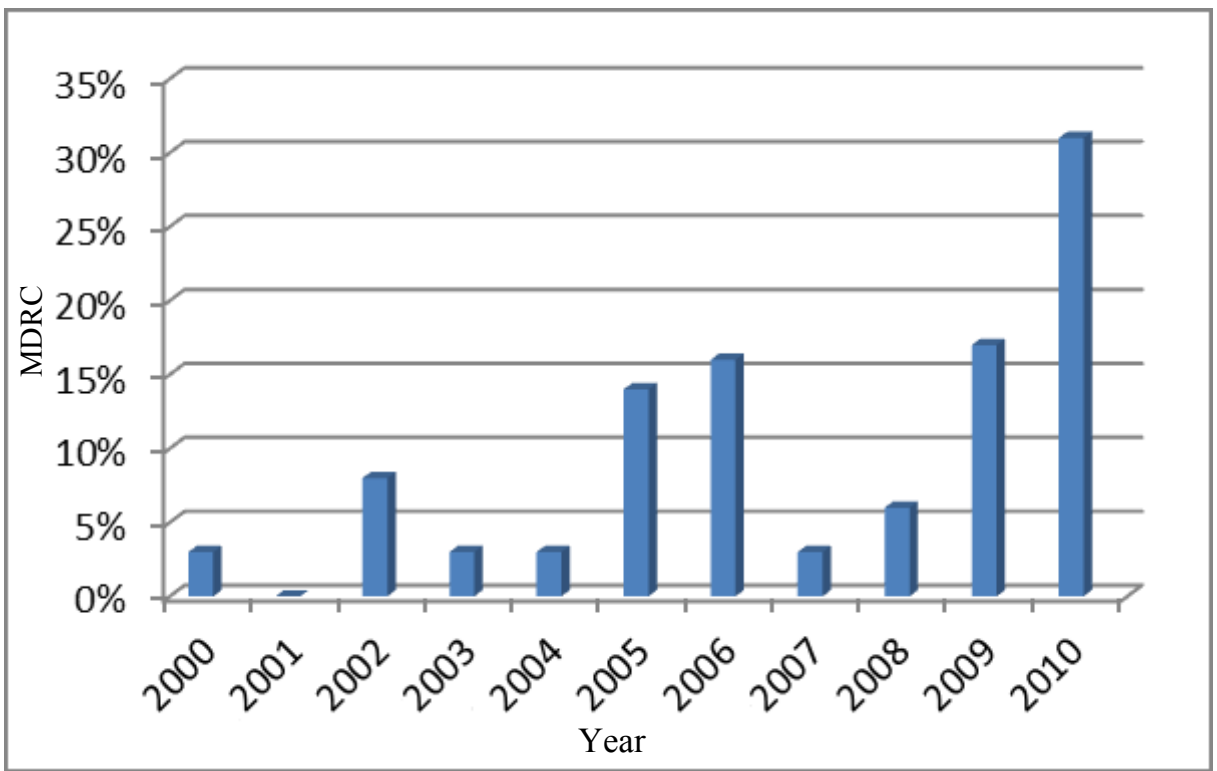

Fig. 1 Measures for delay risks control (2000-2010).

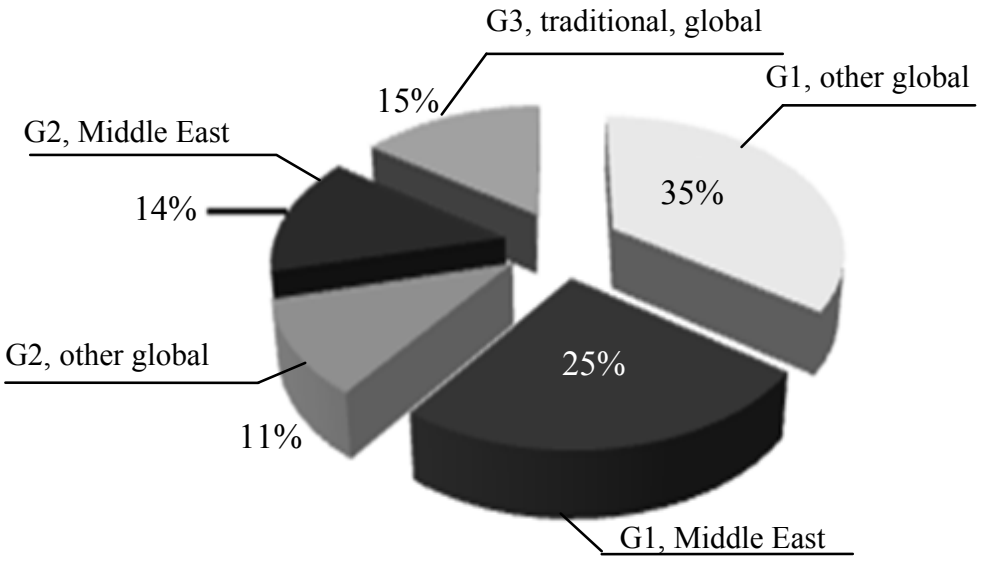

Fig. 2 Measures for delays risks control in the Middle East and worldwide.

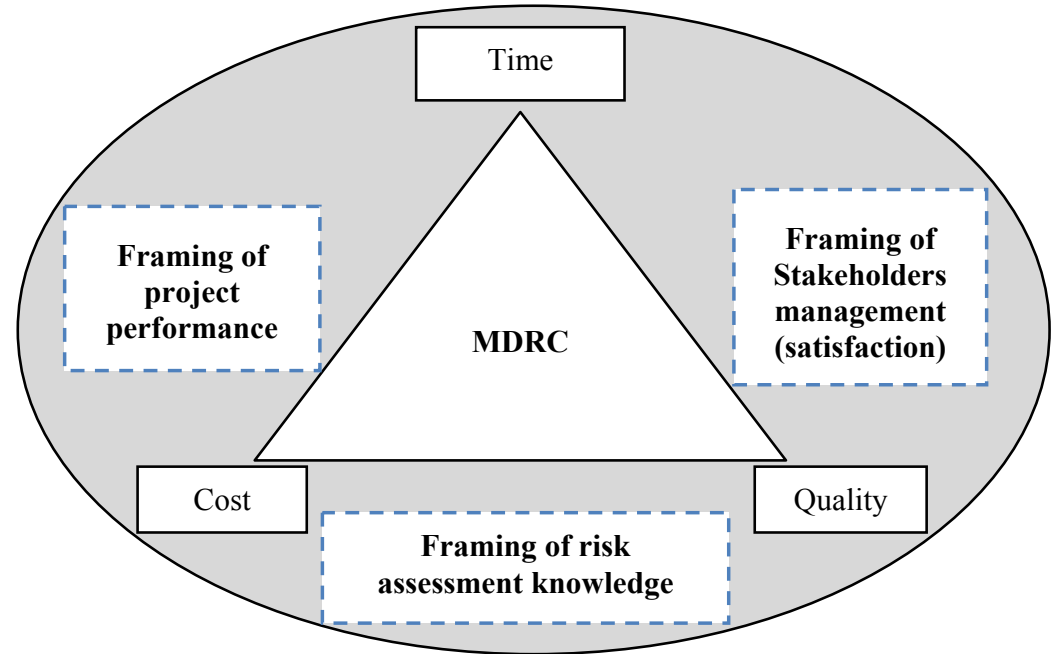

Fig. 3 The proposed future model of MDRC for project success. 
The fact that the lack of knowledge in risk management and performance appears as the top ranking shows that stakeholders, particularly those in the Middle East region, must think beyond the traditional measures. A new model of MDRC and project success is therefore presented in Fig. 3

As shown in Fig. 3, this indicates three levels at which the MDRC should be considered: issues related to the stakeholders' management in terms of greater depth of knowledge. The project can be classed as successful if it gives: (1) stakeholders satisfaction; (2) quality of performance; (3) advance knowledge in risk assessment. It is unlikely that project delays can be controlled if stakeholder management is not added to the traditional success criteria. Furthermore, the mind-set relating to performance management should be transformed from the functional approach to one which is strategy-focused, and this should be undertaken by governmental organizations such as municipalities.

From the authors' point of view, additional measures may encourage greater interaction and stronger relationships among stakeholders. This will enable greater opportunities for changes to be predicted in the early stages of the project life cycle and for the disruptive effects of these to be minimized. Moreover, if time is included for risk assessment in the early stages of the project life cycle, the project team can be assisted in its decision-making and consequently, project performance can be improved with the result that stakeholder expectations can be met.

\section{Conclusions and Further Research}

After conducting the literature review, several conclusions regarding opportunities for further research are identified.

The potential risk management factors influencing the success of stakeholder management have not yet been fully developed. Most of the studies reviewed were focused on stakeholder management in controlling delays risks. Only a few considered the stakeholders' perceptions of risk assessment as antecedents of possible events and responses and the principles of delays control in risk management measures.

The range of practical approaches such as in-depth investigation and integration which are necessary to ensure quality in project performance has not yet been fully considered.

A framework is proposed for structuring effective delays risks control measures. This involves conducting effective risk assessment (knowledge), including stakeholder management and increasing knowledge concerning the performance. The framework is offered in the light of the empirical evidence on the context-specific feature of construction delay in the Middle East, particularly on project nature and objectives base. The model helps to move the scope of the research one step further along the pathway towards understanding the process to secure project success in different environments. The limitations of previous studies suggest that there has been an inappropriate validation of delay risks control measures.

This study reflects the general view, but more in-depth investigation is required in other regions to enable comparison and validation of the findings with other studies. It is recommended that:

- In practical terms, risk management organizations in the Middle East should provide integrated training containing appropriate knowledge for society in general. This should become part of a well-defined approach to risk management, and it requires more experts in risk management who can provide both general and specific training of various kinds to ensure that effective risk assessment knowledge is developed;

- The framework should be developed further to become more practical and ensure that the lesson learned aspect is highlighted. It is accepted that the research into the quality of performance and 
stakeholders management to ease the approach to the identification and assessment of the prioritized risks associated with risk response;

- This framework should be trialed with more real-life cases that have experienced delay risks since the recent financial crisis began in 2008-2009. Observations should relate to real case studies that will be conducted from project managers' departments in construction companies in one or more countries in the Middle East and hence, more information will be forthcoming. Hence, more research could be undertaken with project staff to enhance the knowledge and understanding in the area;

- Generally, project managers should perceive the framework as being suitable for project success with both large and small projects. In addition, it is recommended that the development of regulations is essential to ensure the framework components' integration and optimization.

\section{References}

[1] Project Management Institute Standards Committee. 1996. A Guide to the Project Management Body of Knowledge (PMBOK). Pennsylvania: Project Management Institute.

[2] Mitchell, R. K., Agle, B. R., and Wood, D. J. 1997. "Toward a Theory of Stakeholder Identification and Salience: Defining the Principle of Who and What Really Counts." Academy of Management Review 22 (4): 853-86.

[3] Moodley, K. 2002. "Project Stakeholders." In Engineering project management, edited by Smith, N. J. 3nd ed.. London: Blackwell, 127-36.

[4] Royer, P. S. 2000. "Risk Management: The Undiscovered Dimension of Project Management." Project Management Journal 31 (1): 6-13.

[5] Artto, K. A., Eloranta, K., and Kujala, J. 2008. "Subcontractors Business Relationships As Risk Sources in Project Networks." International Journal of Managing Projects in Business 1 (1): 88-105.

[6] Klemetti, A. 2006. Risk Management in Construction Projects Network. Espoo: Helsinki University of Technology.

[7] Wilson, M. 2010. "Vertical Landscraping: A Big Regionalism for Dubai." International Journal of Urban and Regional Research 34 (4): 925-40.

[8] Sweis, G. 2008. "Delays in Construction Projects." International Journal of Project Management 26 (6):
665-74.

[9] Odeh, A., and Baittaineh, H. 2002. "Causes of Construction Delay: Traditional Contracts." International Journal of Project Management 20 (1): 67-73.

[10] Koushki, P., Parviz, A., and Kartam, N. 2004. "Impact of Construction Materials on Project Time and Cost in Kuwait." Engineering, Construction and Architectural Management 11 (2): 126-32.

[11] Koushki, P. A., Al-Rashid, K., and Kartam, N. 2005. "Delays and Cost Increases in the Construction of Private Residential Projects in Kuwait." Construction Management and Economics 23 (3): 285-94.

[12] Assaf, S., and Al-Hejji, S. 2006. "Causes of Delay in Large Construction Projects." International Journal of Project Management 24 (4): 349-57

[13] Faridi, A. S., and El-Sayegh, S. M. 2006. "Significant Factors Causing Delay in the UAE Construction Industry." Construction Management and Economics 24 (11): 1167-76

[14] Motaleb, O. 2009. "An Investigation into Causes and Effects of Construction Delays in the UAE." M.Sc. dissertation (unpublished), The Robert Gordon University.

[15] Alnuaimi, A., Taha, R., Mohsin, M., and Al-Harthi, A. 2010. "Causes, Effects, Benefits and Remedies of Change Orders on Public Construction Projects in Oman." Journal Construction Engineering and Management 136 (5): 615-22.

[16] Khoshgoftar, M., Abu-Bakar, A., and Osman, O. 2010. "Causes of Delays in Iranian Construction Projects." International Journal of Construction Management 10 (2): 53-69.

[17] Khamis, M., and Senhadji, A. 2010. Impact of the Global Financial Crisis on the Gulf Cooperation Council Countries and Challenges Ahead. Washington, D.C.: IMF (International Monetary Fund) Middle East and Central Asia Department.

[18] Shenhar, A. J., Dvir, D., and Levy, O. 1997. "Mapping the Dimensions of Project Success." Project Management Journal 28 (1): 5-13.

[19] Alarcon, L. F., Grillo, A., Freire, J., and Diethelm, S. 1998. "Learning from Collaborative Benchmarking in the Construction Industry." In: Proceedings of the Ninth Conference of International Group for Lean Construction, 407-15.

[20] Low, S., and Chuan, Q. 2006. "Environmental Factors and Work Performance of Project Managers." International Journal of Project Management 21 (1): 24-37.

[21] Dweiri, F. 2006. "Using Fuzzy Decision Making for the Evaluation of the Project Management Internal Efficiency." Decision Support Systems 42 (2): 712-26. 
[22] Hasna, A., and Raza, S. 2010. "The Status of Project Portfolio Management Practices Adoption and Awareness in Gulf Cooperation Counties: An Empirical Study." International Journal of Project Organisation \& Management 2 (2): 174-92.

[23] Mulkahy, R. 2005. PMP Exam Preparation for the $P M B O K$ Guide. 6th ed.. USA: PMI (Project Management Institute).

[24] Williams, R. 2008. "Underwriting T5-The Perfect Storm." Presented at the IMIA (International Association of Engineering Insurers) Conference, Gleneagles.

[25] Beatham, S., Anumba, C., Thorp, T., and Hedges, I. 2004. "KPIs: A Critical Appraisal of Their Use in Construction." Benchmarking 11 (1): 93-117.

[26] Chan, A., and Chan, A. P. L. 2004. "Key Performance Indicators for Measuring Construction Success." Benchmarking 11 (2): 203-21.

[27] Ling, F. Y. Y., Low, S. P., Wang, S. Q., and Lim, H. H. 2009. "Key Project Management Practices Affecting Singaporean Firms Project Performance in China." International Journal of Project Management 27 (1): 59-71.

[28] Toor, S., and Ogunlana, S. 2010. "Beyond the Iron Triangle: Stakeholder Perception of Key Performance Indicators (KPIs) for Large-Scale Public Sector Development Projects." International Journal of Project Management 28 (3): 228-36.

[29] Shenhar, A. 2004. "Strategic Project Leadership: Toward a Strategic Approach to Project Management." $R \& D$ Management 34 (5): 569-78.

[30] Landin, A. 2000. "Impact of Quality Management on the Swedish Construction Process." Ph.D. thesis, Lund University.

[31] Bakens, W., Foliente, G., and Jasuja, M. 2005. "Engaging Stakeholders in Performance-Based Building: Lessons from the Performance-Based Building (PeBBu) Network." Building Research \& Information 33 (2): 149-58.

[32] Young, T. L. 2006. Successful Project Management. 2nd ed.. London: Kogan.

[33] Barber, E., and Warn, J. 2005. "Leadership in Project Management: From Fire Fighter to Fire Lighter." Management Decision 43 (7): 1032-9.

[34] Aibinu, A., and Jagboro, G. 2002. "The Effects of Construction Delays on Project Delivery in Nigerian Construction Industry." International Journal of Project Management 20 (8): 593-9.

[35] Al-Momani, A. H. 2000. "Construction Delay: A Quantitative Analysis." International Journal of Project Management 18 (9): 51-9.

[36] Motaleb, O., and Kishk, M. 2013. "An Investigation into the Risk of Construction Project Delays in the UAE."
International Journal of Information Technology in Project Management 4 (3): 50-65.

[37] Arain, F. 2005. "A Framework for Developing a Knowledge-Based Decision Supports System for Management of Variations Order for Institutional Buildings." ITcon 11: 285-307.

[38] Al-Khalil, M. I., and Al-Ghafly, M. A. 1999. "Delays in Public Utility Projects in Saudi Arabia." International Journal of Project Management 17 (2): 101-6.

[39] Luu, V., Kim, S., Tuan, N., and Ogunlana, S. 2009. "Quantifying Schedule Risk in Construction Projects Using Bayesian Belief Networks." International Journal of Project Management 27 (1): 39-50.

[40] Ahmed, S. M., Azhar, S., Kappagantula, P., and Gollapudi, D. "Delays in Construction: A Brief Study of the Florida Construction Industry." In Proceedings of 39th Annual Scientific Conference, 257-66.

[41] Harries, F. C., and McCaffer, R. 2001. Modern Construction Management. 5th ed.. Oxford: Blackwell Science.

[42] Construction Industry Working Group on Payment. 2007. The Importance of Payment in the Construction Industry. Report on Enactment of Construction Industry Payment and Adjudication Act.

[43] Abdul-Rahman, H., Berawi, M., Berawi, A., Mohamed, O., Othman, M., and Yahya, I. 2006. "Delay Mitigation in the Malaysian Construction." Industry Journal Construction Engineering and Management 132 (2): 125-34.

[44] Habibi, N. 2009. "Impact of the Global Economic Crisis on Arab Countries: A Year-End Assessment." Middle East Brief 40: 10.

[45] Ng, S., Deng, M., Lam, K., and Skitmore, R. 2000. "A Conceptual Case-Based Decision Model for Construction Delays Mitigation." International Journal of Construction Information Technology 8 (2): 1-20.

[46] Shenhar, A. J., Tishler, A., Dvir, D., Lipovetsky, S., and Lechler, T. 2002. "Risk Management, Project Success, and Technological Uncertainty." $R \& D$ Management 32 (2): 101-9.

[47] Fernie, S., Green, S., Weller, S., and Newcombe, R. 2003. "Knowledge Sharing: Context, Confusion and Controversy." International Journal of Project Management 21 (3): 177-87.

[48] Nguyen, L., Ogunlana, S., and Lan, D. 2004. "A Study on Project Success Factors in Large Construction Projects in Vietnam." Engineering, Construction and Architectural Management 11 (6): 404-13.

[49] Lee, S., Peña-Mora, F., and Park, M. 2005. "Quality and Change Management Model for Large Scale Concurrent Design and Construction Projects." Journal of Construction Engineering and Management 131 (8): 
890-902.

[50] Lee, H., Ryu, H., Yu, J., and Kim, J. 2005. "Method for Calculating Schedule Delay Considering Lost Productivity." Journal of Construction Engineering and Management 131 (11): 1147-54.

[51] Oliveros, A., and Fayek, A. 2005. "Fuzzy Logic Approach for Activity Delay Analysis and Schedule Updating." Journal of Construction Engineering and Management 131 (1): 42-51.

[52] Wang, X., and Huang, J. 2006. "The Relationships between Key Stakeholders Project Performance and Project Success: Perceptions of Chinese Construction Supervising Engineers." International Journal of Project Management 24 (5): 253-60.

[53] Shahalizade, M., and Farhadyar, A. 2006. "A Study on Delays Causes of Gas Transmission Pipeline Projects in Iran: A Risk and Knowledge Management Approach.” Presented at the 7th Asia Pacific Industrial Engineering and Management Systems Conference, Bangkok, Thailand.

[54] Zaneldin, E. 2006. "Construction Claims in United Arab Emirates: Types, Causes and Frequency." International Journal of Project Management 24 (5): 453-9.

[55] Arditi, D., and Pattanakitchamroon, T. 2006. "Selecting a Delay Analysis Method in Resolving Construction Claims." International Journal of Project Management 24 (2): 145-55.

[56] Oladapo, A. 2007. "A Quantitative Assessment of the Cost and Time Impact of Variation Orders on Construction Projects." Journal of Engineering, Design and Technology 5 (1): 35-48.

[57] Zeng, J., Ann, M., and Smith, N. 2007. "Application of a Fuzzy Based Decision Making Methodology to Construction Project Risk Assessment.” International Journal of Project Management 25 (6): 589-600.

[58] Abdul-Rahamn, H., Yahya, I., Alberawi, M., and Wah, L. 2008. "Conceptual Delay Mitigation Model Using Project Learning Approach in Practice." Construction Management and Economics 26 (1): 15-27.

[59] Abdul-Rahman, H., Takim, R., and Min, W. 2009. "Financial-Related Causes Contributing to Project Delays." Journal of Retail and Leisure Property 8 (3): 225-38.

[60] Tumi, S., Omran, A., and Pakir, A. 2009. "Causes of Delay in Construction Industry in Libya." In Proceedings of the International Conference on Economics and
Administration, 265-9.

[61] Said, M. 2009. "Improved Schedule Analysis Considering Rework Impact and Optimum Delay Mitigation." M.Sc. thesis, University of Waterloo.

[62] Motaleb, O., and Kishk, M. 2010. "An Investigation into Causes and Effects of Construction Delays in the UAE." In Proceedings of 26th Annual Association of Researchers in Construction Management Conference, 1149-57.

[63] Thanh, N. X., and Dapice, D. 2001. "Vietnam's Infrastructure Constraints." Harvard Kennedy School. Accessed January 15, 2011. http://www.innovations.harvard.edu/cache/documents/65 33/653317.pdf.

[64] Preston, M. 2011. "Gulf Construction-Legally Bound Financial Risk Part of Every Project." Accessed January 15, 2011. http://www.nortonrose.com/news/inthepress/ news30861.aspx?lang=en-gb.

[65] Omran, A., Ling, O., Pakir, A., and Ramli, M. 2010. "Delays Factors in Construction Projects Development: The Case of Klang Vally, Malaysia." Journal of Academic Research in Economics 2 (2): 135-58.

[66] Olawale, Y. A., and Sun, M. 2010. "Cost and Time Control of Construction Projects: Inhibiting Factors and Mitigating Measures in Practice." Construction Management and Economics 28 (5): 509-26.

[67] Manase, D. 2010. "The Impact of the Global Financial Crisis on Client Procurement Behaviour in the UK Construction Industry: The Case of PFI." Accessed January 15, 2011. http://www.rics.org/.

[68] Arditi, D., Polat, G., and Akin, S. 2010. "Lessons Learned System in Construction Management." International Journal of Project Organisation and Management 2 (1): 61-83.

[69] Brendel, N., Barrette, A., and El-Riachi, W. 2010. "The Availability in the UAE of Liens to Secure Payment under Construction Contracts." Arab Law Quarterly 24 (3): 309-17.

[70] Al-Tmeemy, S., Abdul-Rahman, H., and Harun, Z. 2010. "Future Criteria for Success of Building Projects in Malaysia." International Journal of Project Management 29: 337-48.

[71] Abdul-Rahman, H., Wang, C., Takim, R., and Wong, S. 2011. "Project Schedule Influenced by Financial Issues: Evidence in Construction Industry." Scientific Research and Essays 6 (1): 205-12. 